\title{
PERILAKU RIBA KEBIASAAN MASYARAKAT SESAT TIDAK SESUAI PRINSIP-PRINSIP SYARIAH ISLAM
}

\author{
Herlina Kusuma Wardani \\ Ikatan Ahli Ekonomi Islam (IAEI), Jawa Tengah, Indonesia \\ Email: herlina-orlin@gmail.com
}

\begin{abstract}
Abstrak
Usury is an income gained arbitrarily or unfairly from one party to another. Riba in outline is divided into two, namely usury nasi'ah and usury fadhl. The human habit that makes usury is a belief that is not only perverted, but besides heresy is also misleading. A person who behaves in usury means clearly and openly as an opponent of Allah azza wajalla and Rasulullah SAW. Truly hostile to Allah and His Messenger will be a major step in Shaitan's deviance of men. Allah SWT and Rasulullah SAW will also openly combat the behavior of usury. The behavior of usury is not compatible with the principles of Islamic sharia. Even because the behavior of usury and misleading, so that the adzab Allah will be inflicted not only to the perpetrators of usury, but people who do not do it if living in a society that behaves in usury affected adzab.
\end{abstract}

Keywords: usury, astray, principles of shari'a Islam

\section{Pendahuluan}

Riba merupakan suatu pendapatan yang di peroleh dengan semena-mena atau secara tidak adil(dholim) dari satu pihak kepada pihak yang lain. Padahal sesuatu muamalah itu akan sah jika diantara pihak yang melakukan atau bersinggungan tidak ada yang mendholimi dan didholimi.Sebagaimana firman Allah SWT berikut ini:

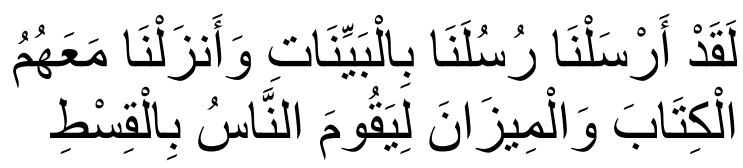

"Sesungguhnya Kami telah mengutus rasulrasul Kami dengan membawa bukti-bukti yang nyata, serta telah Kami turunkan bersama mereka al-Kitab dan neraca (keadilan) supaya manusia dapat melaksanakan keadilan." (Qs. al-Hadid: 25).

Hal tersebut dipertegas pula oleh hadis Rasulullah SAW, berupa hadis qudsi yang sangat gamblang sebagai berikut:

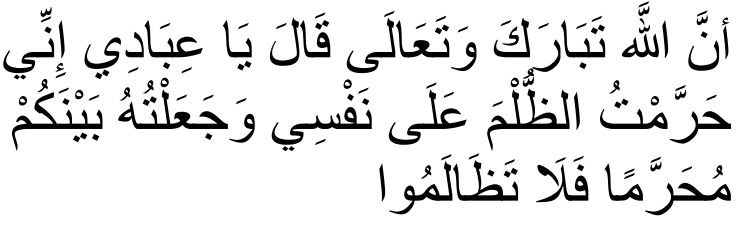

"Sungguh, Allah telah berfirman, 'Wahai hamba-Ku, sungguh aku telah mengharamkan kezaliman atas diri-Ku dan menjadikannya terlarang di antara kalian, maka janganlah saling menzalimi!' " (Hr. Muslim)

Praktek riba yang ada di tengah-tengah masyarakat telah menjamurdan berkembangdalam berbagai kegiatan aktivitas manusia sejak zaman jahiliyah (sebelum datangnya agama Islam)sampaisaat ini. Sejak zaman dahulu banyaknya persoalan-persoalan ekonomi yang terjadi serta telah menjadi tradisi atau kebiasaan oleh bangsa arab saat itu terhadap pinjam-meminjam barang dan jasa atau kegiatan jual beli. Sehingga kegiatan semacam itu sudah mendarah dagingserta menjadi kebiasaan dikalangan masyarakat saat itu jauh sebelum datangnya Nabi Muhammad SAW, dimana transaksi yang terjadi saat itu, 
mereka memberikan pinjaman kepada seseorang,kemudian mereka memungut biaya jauh lebih tinggi dari besarnya pinjaman semula yang di berikan kepada peminjam, sehinggabanyak orang orang tidak menyadari akan bahayadan larangan riba, tidak menyadarinya bukan karena mereka tidak tahu, namun terkadang mereka justru menganggapnya sesuatu yang wajar-wajar saja. Padahal sesungguhnya kalau sudah menjadi kebiasaan, maka perilaku riba tidak lagi menjadi perilaku yang sesat, tetapi perilaku riba itu sesat dan menyesatkan. Dengan demikian, adzab yang akan ditimpakan tidak hanya bagi para pelakunya, tetapi semua masyarakat yang ada disekitar para pelaku riba yang tidak melakukan sekalipun akan diperangi oleh Allah dan RasulNya.

Begitu maraknya berbagai kegiatan atau muamalah manusia yang bersingungan dengan riba, inilah yang harus menjadi perhatian serius kita bersama. Karena sesungguhnya riba sangat jelas telah diharamkan oleh berbagai agama, tidak hanya agama Islam. Menurut Tho'in (2016: 64) bahwa riba telah disepakati keharamannya oleh seluruh ulama bahkan oleh seluruh syariat langit, dengan kata lain riba tidak hanya diharamkan oleh agama Islam saja, tetapi agama-agama samawi yang lainpun juga mengharamkannya.

Dengan demikian, dalam pembahasan artikel ilmiah kali ini akan mencoba mengupas perilaku yang sering terjadi di kalangan masyarakat disekitar kita yang beranggapan bahwa perilaku riba merupakan perilaku yang biasa-biasa saja, padahal keyakinan semacam itu jelas adanya sebagai keyakinan yang sesat dan menyesatkan.

\section{Pembahasan}

\section{Pengertian Riba}

Riba adalah penetapan bunga atau melebihkan jumlah pinjaman saat pengembalian berdasarkan persentase tertentu dari jumlah pinjaman pokok yang dibebankan kepada peminjam. Riba secara bahasa bermakna tambahan. Dalam pengertianlain, secara linguistik riba juga berarti tumbuh dan membesar (Wikipedia Bahasa Indonesia)

Pengertian riba secara bahasa dapat diartikan sebagai tambahan (ziyadah) atau dengan kata lain tumbuh dan membesar dan menjadi banyak. Riba adalah melebihkan keuntungan yang didapatkan seseorang dari salah satu pihak kepada pihak yang lain dalam transaksi jual beli atau pertukaran barang yang sejenis tanpa memberikan imbalan terhadap kelebihan itu atau yang sering disebut dengan riba fadl; atau pembayaran atas hutang yang harus di lunasi oleh orang yang telah berhutang, dimana jumlah pelunasan tersebut lebih besar dari pada jumlah dana yang dipinjam tersebut, sebagai imbalan terhadap tenggang waktu yng telah lewat atau yang sering disebut dengan riba nasi'ah.

Sedangkan pengertian usury atau riba secara terminologi fiqh adalah riba merupakan tambahan khusus yang dimiliki salah satu dari dua pihak yang terlibat transaksi tanpa ada imbalan tertentu.

Kemudian pandangan ulama terutama menurut Syaikh Muhammad Abduh, bahwa riba merupakan penambahan yang sebelumnya telah diisyaratkan oleh orang yang memiiki harta (uang) kepada orang yang meminjam hartanya tersebut, karena telah terjadi pengunduran janji atas pembayaran pinjaman tersebut oleh peminjam dari batas waktu yang telah ditentukan kedua belah pihak (Suhendi, 2007: 57-58). 


\section{Macam-macam Riba}

Secara garis besar para ulama-ulama kita telah membagi riba menjadi dua, yaitu riba nasi'ah (arahnya dari pinjaman uang) dan riba fadhl (arahnya kelebiahan barang dari transaksi jual beli atau tukar menukar).

1. Riba atas tambahan pinjaman (Riba Nasi'ah), merupakan riba yang diperoleh dari adanya tambahan pokok pinjaman yang diisyaratkan dan diambil oleh pemberi pinjaman dari yang berhutang sebagai kompensasi atas tangguhan pinjaman yang diberikannya tersebut (Sabiq, 2013: 107). Allah melarang keras kegiatan pinjam meminjam uang yang menghasilkan tambahan dikemudian harinya saat pelunasan sebagaimana firman Allah SWT Surah Al-Baqarah: 280 dibawah ini:

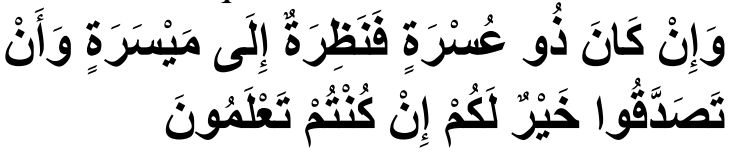

"Dan jika (orang yang berhutang itu) dalam kesukaran, Maka berilah tangguh sampai dia berkelapangan. dan menyedekahkan (sebagian atau seтиa utang) itu, lebih baik bagimu, jika kamu mengetahui." (Kementerian Agama, 2010: 47).

Dari surah al-Baqarah ayat 280 tersebut, dapat ditarik kesimpulan sebagai berikut: jika seseorang yang berhutang telah jatuh tempo hutangnya tersebut, tetapi orang yang berhutang tersebut masih dalam keadaan kesulitan untuk membayar hutangnya tersebut, maka orang yang memberikan hutang atau pinjaman tersebut hendaklah bersabar dan tidak pula menagih orang yang berhutang tersebut. Sedangkan jika orang yang berhutang itu telah memiliki uang dan dirinya pula dalam keadaan lapang (cukup), maka wajib baginya untuk segera membayar hutangnya tersebut kepada pihak yang menghutanginya, dan orang yang berhutang JURNAL ILMIAH EKONOMI ISLAM, ISSN: 2477-6157 ; E-ISSN 2579-6534 tersebut tidak perlu menambah nilai dari tanggungan hutang yang dipinjamnya itu, baik orang yang berutang tersebut sedang memiliki uang atau sedang keadaan sulit (Fauzan, 2006: 390-391). Dari ayat tersebut ada yang lebih mulia lagi, dimana ketika orang yang berhutang dalam keadaan kesulitan untuk membayar hutangnya, maka hendaklah orang yang memberikan hutang mengikhlaskannya, karena Allah SWT akan menggantikan uang utang yang ia ikhlaskan dengan bahala sedekah dan bahkan akan dilipatgandakan dari arah yang tak terduga.

2. Riba barang (uang juga bisa dimasukkan dalam obyek barang) atau Riba Fadhl, merupakan riba yang timbul dari sesuatu yang sejenis yang disertai tambahan, dapat berupa uang, atau dapat pula berupa makanan (Sabiq, 2013: 107). Riba Fadhl diambil dari kata alfadhl, yang memiliki arti tambahan dari salah satu jenis barang yang dipertukarkan dalam proses transaksi (tukar menukar) atau dengan kata lain pertukaran barang sejenis yang menimbulkan tambahan. Di dalam larangan berupa keharamannya terhadap riba ini, syariat telah memutuskan dalam enam hal terhadap barang-barang yang terkait riba fadhl, yaitu: emas, perak, gandum putih, gandum merah, kurma, dan garam. Jika barang-barang tersebut di atas (enam barang) ditransaksikan atau ditukarkan sejenis disertai dengan adanya tambahan, maka hal tersebut merupakan pertukaran yang mengandung riba dengan demikian haram hukumnya. Sebagaimana yang dijelaskan dalam hadits Rasulullah SAW berikut ini yang diriwayatkan oleh Ahmad dan Muslim: 


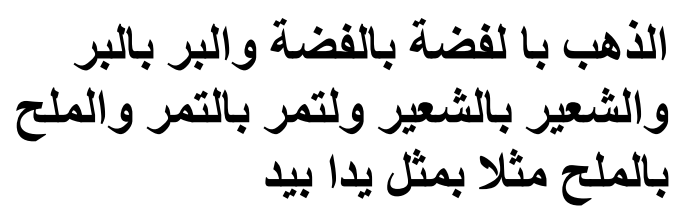

"Emas dengan emas, perak dengan perak, gandum putih dengan gandum putih, gandum merah dengan gandum merah, kurma dengan kurma, (dalam memperjualbelikannya), harus dengan ukuran yang sama, dan diterima secara langsung”(Fauzan, 2006: 391-392).

\section{Kebiasaan}

Islam sangat menghormati kebiasaan masyarakat selama kebiasaan tersebut tidak bertentangan dengan syariat Islam, walaupun tidak ada perintahnya tetapi tidak ada pula larangannya. Karena kebiasaan yang dimaksud disini adalah kebiasaan dalam hal muamalah seperti tukar menukar, jual beli dan sebagainya. Karena sesungguhnya kebiasaankebiasaan yang tidak ada larangan atasnya (urf') justru dapat dijadikan pijakan dalam meningkatkan kemaslahatan selama perbuatan kebiasaan tersebut sesuai dengan prinsipprinsip syariah Islam. Menurut Tho'in (2016) Peraturan atau hukum dalam menjalankan serta mengamalkan agama Allah adalah termasuk syariah Islam.

AI-'Urf adalah sesuatu yang diterima oleh tabiat dan akal sehat manusia, sering disinonimkan dengan 'adat kebiasaan. Urf dari sudut pandang bahasa memiliki arti sesuatu yang dipandang baik serta diterima oleh akal sehat manusia. Sedangkan menurut istilah 'urf merupakan sesuatu yang sebelumnya telah sering dikenal oleh manusia kemudian sesuatu tersebut telah menjadi tradisinya, baik berupa ucapan atau perbuatannya. Ada pula seseorang yang mendefinisikan pengertian dari urf' adalah sesuatu yang dikenal oleh banyak orang atau masyarakat di mana mereka (orang JURNAL ILMIAH EKONOMI ISLAM, ISSN: 2477-6157 ; E-ISSN 2579-6534 atau masyarakat tersebut) dapat melakukan hal tersebut, baik berupa suatu perkataan maupun suatu perbuatan (Wahab, 1993: 134).

Sebaliknya kebiasaan yang telah ada larangannnya, seperti perilaku riba yang sering terjadi di masyarakat sampai saat ini merupakan perilaku yang jelas-jelas telah dilarang oleh Allah dan RasulNya. Bahkan Allah SWT dan Rasulullah SAW terangterangan akan memerangi para perilaku riba ini. Sebagaimana dengan firman Allah SWT:

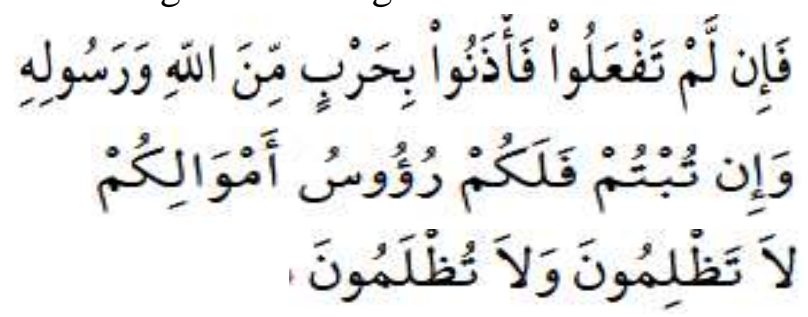

Maka jika kamu tidak mengerjakan (meninggalkan sisa riba), maka ketahuilah, bahwa Allah dan Rasul-Nya akan memerangimu. Dan jika kamu bertobat (dari pengambilan riba), maka bagimu pokok hartamu; kamu tidak menganiaya dan tidak (pula) dianiaya. (QS Al-Baqarah : 279).

\section{Riba Perilaku Sesat}

Riba memberikan dampak yang sangat buruk bagi akhlak (budi pekerti) dan kejiwaaan para pelakunya. Jika kita perhatikan secara detail dengan sesama, maka kita akan melihat serta menemukan bahwa mereka yang berinteraksi atau berperilaku dengan riba dalam kehidupan sehari-harinya adalah individu yang memiliki sifat-sifat yang tidak terpuji seperti kikir, sombong, pendengki, serakah terhadap kemewahan dunia dan cenderung takut akan kematian (wan).

Seseorang yang berperilaku riba berarti secara jelas serta terang-terangan sebagai penentang Allah azza wajalla dan rasul-Nya dan dirinya layak diperangi oleh Allah dan rasul-Nya. Bahkan baginya kesesatan yang nyata untuk selama-lamanya. Karena perilaku 
riba juga merupakan perilaku yang sangat disukai syaitan.

Sesungguhnya memusuhi Allah dan Rasul-Nya akan menjadi langkah utama syaitan dalam menyesatkan manusia. Dengan menjadikan manusia memusuhi Allah dan Rasul-Nya, salah satunya dengan melakukan interaksi yang mengandung riba inilah yang menjadi langkah pertama yang dilakukan setan, barulah ketika itu ia beristirahat dari rasa capeknya. Setan akan terus berusaha menggoda dan terus menyesatkan manusia agar bisa terjerumus dalam dosa pertama ini. Jika yang dilakukan syaitan itu berhasil, pasukan dan bala tentara mereka ini akan diangkat menggantikan posisi iblis.

\section{Kesimpulan}

Riba merupakan suatu pendapatan yang di peroleh dengan semena-mena atau secara tidak adil dari satu pihak kepada pihak yang lain. Riba secara garis besar terbagi menjadi dua, yaitu riba nasi'ah dan riba fadhl. Kebiasaan manusia yang menjadikan perilaku riba merupakan sebuah keyakinan yang tidak hanya sesat, tetapi selain sesat juga menyesatkan.

Seseorang yang berperilaku riba berarti secara jelas serta terang-terangan sebagai penentang Allah azza wajalla dan rasul-Nya. Sesungguhnya memusuhi Allah dan RasulNya akan menjadi langkah utama syaitan dalam menyesatkan manusia. Allah SWT dan Rasulullah SAW pun juga terang-terangan akan memerangi para perilaku riba. Perilaku riba sesat tidak sesuai prinsip-prinsip syariah Islam Bahkan karena perilaku riba sesat dan menyesatkan, sehingga adzab Allah akan ditimpakan tidak hanya kepada pelaku riba saja, tetapi masyarakat yang tidak melakukannyapun apabila hidup dalam masyarakat yang berperilaku riba ikut terkena adzab.

\section{Daftar Pustaka}

Fauzan (-al), Saleh. (2006). Fiqh Sehari-hari, Cetakan ke-1, Jakarta: Gema Insani.

Kementerian Agama. (2010). Terjemahan Tafsir Perkata. Cetakan ke-1, Bandung: Sygma.

Sabiq, Sayyid. (2013). Fiqh Sunnah. Cetakan ke-1, Jakarta: Tinta Abadi Gemilang.

Suhendi, Hendi. (2007). Fiqh Mu'amalah, Jakarta: Raja Grafindo Persada.

Tho'in, M. (2016). Kompetensi Sumber Daya Manusia Bank Syariah Berdasarkan Prinsip-Prinsip Syariah Islam (Studi Kasus Pada BNI Syariah Surakarta). Jurnal Ilmiah Ekonomi Islam, 2(03).

Tho'in, M. (2016). Larangan Riba Dalam Teks Dan Konteks (Studi Atas Hadits Riwayat Muslim Tentang Pelaknatan Riba). Jurnal Ilmiah Ekonomi Islam, 2(02).

Wahab, Abdul. (1993). Kaidah-Kaidah Hukum Islam. Jakarta: Rajawali.

Wikipedia Bahasa Indonesia, ensiklopedia bebas.https://id.wikipedia.org/wiki/Riba. diakses pada hari Kamis 2 Februari 2017. 